\title{
A HOUSE IN HISTORY, HERITAGE AND TOURISM: SHifting Times AT BLUNDELL'S COTtAGE, CANBERRA
}

\author{
LINDA YOUNG \\ Public History ReVIeW, Vol 12, 2006, PP44-57
}

$\mathrm{T}$

his is the story of how a house became heritage - a history of the construction of heritage by locals, bureaucrats and planners, romantics, revisionists and professionals. The house now known as Blundell's Cottage constitutes a microcosm of the history of activism in Australian heritage conservation, from the local historical society to the Register of the National Estate to the assets of cultural tourism. The discourses that shaped the house's preservation have shifted three times in fifty years as has its management regime.

This article introduces the house as a dwelling, then as an element of a managed landscape, and gradually as an item of public cultural infrastructure. Next I review the house within a history of changing regimes of heritage management: beginning as a relic worthy of 'saving', becoming a minor tourist attraction and increasingly constituting an object of professional heritage managers' attention. Last, I survey the character of Australian history presented via the preservation of the building, its curtilage and the objects displayed.

While the article is structured by the methods of history it is also coloured by the voice of my own experience, for I was a voluntary guide, a member and later Chair of the Board of Management and a heritage professional with expertise in site and collections management. I took a lot of pleasure in my involvement with Blundell's Cottage: satisfactions grounded in personal interactions, professional achievements and the sense of contributing to the conservation of my local history. Despite having heavy duty credentials, I still felt the frustrations of being situated as a volunteer activist in an increasingly professionalised milieu which is a rare experience for those lucky enough usually to be paid for heritage work. I take this opportunity to acknowledge the time and energy of the volunteers who transformed Blundell's for posterity. Canberra people, and perhaps a much broader slice of visitors as well, have been their beneficiaries.

\section{HOUSE HISTORY}

At the time it entered public consciousness as a historic site, Blundell's Cottage was known as Oldfield's farm. The year was 1958 when Alice Oldfield died. She 
had lived there since 1933 with her husband Harry, working a farmlet which supplied milk and eggs to the public servants of embryonic Canberra. The house and its paddocks had originally been part of a large local property, Duntroon, granted in 1825 to Sydney merchant Robert Campbell. ${ }^{1}$ Duntroon was compulsorily acquired by the Commonwealth in 1912 as part of the Federal Capital Territory, destined to become the site of the capital city of Australia.

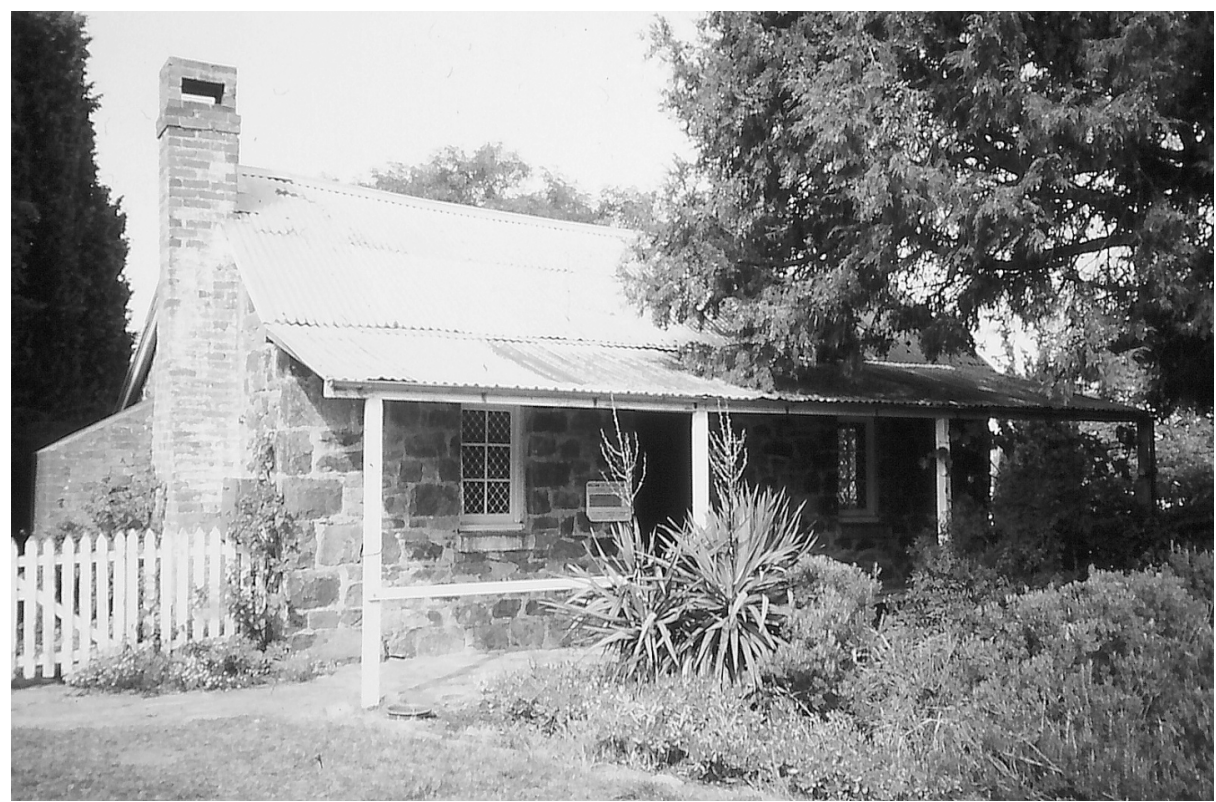

Blundell Cottage 1996. The white picket fence provided by the NCDC restoration of Blundell's Cottage in 1961 has become such a popular fixture that it will be difficult ever to remove. (Photograph Linda Young)

Robert Campbell initiated the first stage of a grand house in 1833 and lived there in the last years of his life. The estate was managed sequentially by sons Charles and George with the labour of a small community of tenant farmers, imported from Scotland to avoid the convict stain. ${ }^{2}$ Some twenty five houses were built on Duntroon for these workers and their families, mainly of slab timber, plus three of brick and three of stone. The Oldfields' house was one of the latter. Constructed of local rubble stone about 1860 in the midst of a major building campaign on the property, its form was a vernacular four-room cottage with a detached slab kitchen at the back. The first inhabitants were William and Mary Ginn and their four children. William was employed on Duntroon as a ploughman and farmed sixty acres as a tenant. He later selected land a few miles north and by 1874 the family had realised the emigrant dream of their own property. ${ }^{3}$

The second family to occupy the cottage were George and Flora Blundell,who moved in as newlyweds in 1874 and lived there all their lives. George had been born on Duntroon estate and worked there as a bullock drive in adulthood. He and Flora brought up eight children in the house which was enlarged about 1890 with a two-room wing at the back. When the Commonwealth acquired Duntroon estate, George took on the lease of his immediate paddocks 
as well as some south of the river. ${ }^{4}$ On his death in 1927 the Oldfields became the third family to occupy the house. It was a second marriage with no children, and Harry and Alice died there, Harry first and Alice, as noted, in 1958. The house was then scheduled for demolition to prepare for the coming of the Walter Burley Griffin-planned lake in $1962 .^{5}$

When Alice Oldfield died the Canberra \& District Historical Society (CDHS) made urgent representations to the Department of the Interior to recognise the house as a historic landmark. A new consciousness of the Canberra valley's history motivated the idea that the place now amounted to a relic of the rural origins of the city and merited preservation. Thanks to the chance that it stood almost opposite (Old) Parliament House on the other side of the Molonglo River, a 1961 review concluded that the house should remain in situ and be restored. The National Capital Development Commission (NCDC) employed Sydney architect Morton Herman to plan the restoration works. He oversaw the removal of the fibro verandah enclosure, the shifting of a water tank from the front to the back of the house, cleaning of the exterior walls, the repairing of cracks, the introduction of the Boncote interior finishes in uniform mushroom pink, the insertion of sturdy new doors and the addition of window shutters for security. ${ }^{6}$

The CDHS became the fourth tenant of the house in 1963. In the interim it had been inhabited by a number of casual residents, for housing was scarce in post-War Canberra. ${ }^{7}$ The Society planned to open an office and reading room and make a museum in the two front rooms; it called for donations of furniture, exhibits and repair materials. 'In keeping with its origin', the Society heroically declined the NCDC offer to connect the house to electricity, water and sewerage. ${ }^{8}$ This was authentic but demanding, and after a few years the cold and dark induced the office and library to depart for modern quarters in Canberra's Civic centre leaving the entire house as a museum. ${ }^{9}$ It was many years before the Society succumbed to electricity in 1986; reticulated water was connected to the garden in 1990 (though the house still relies on tank water); and the last dunny in the parliamentary triangle was replaced by a modern composting toilet in $1998 .{ }^{10}$ Descendants of the cottage's original inhabitants described a multitude of further slab outbuildings, two square ship's tanks for water and wire and postand-rail fences (also to be seen in early twentieth century images). But NCDC landscaping priorities for the edge of the Lake shaped the curtilage and picket fence that still obtain. ${ }^{11}$

The house opened as a museum in 1964, renamed Blundell's Farmhouse to commemorate its longest inhabitants and their rural circumstances. Throughout the 1960s, CDHS members with thermoses and strong bladders held working bees to repair the slab building, install flagstone paths, plant the garden and undertake spring cleaning. Volunteers made plain curtains and rag rugs. Improvements continued throughout the years. The front bedroom, for example, was ceiled in 1971 with boards rescued from the Gribble house in Ginninderra, 'in order to make the Farmhouse conform to its period. ${ }^{12}$ 
The house also had to conform to its new role as a museum, a need demonstrated by the tale of the kitchen. When the house was valued for Commonwealth resumption in 1912, it was described as having a detached slab kitchen with earthen floor and iron roof, the whole in fair condition but very old. ${ }^{13}$ The 1972 guide to the house called the slab building a shed, noting that it had contained the kitchen. Author, Pat Wardle - a reliable historian - cited received wisdom that it had been built in 1879 and implied that it had been slightly moved at some stage. ${ }^{14}$ The latter seems unlikely, and in some years of research I have never found any evidence of a move. It would seem that at least the Blundells, if not the Ginns, used the slab building as the kitchen throughout their lives but that the Oldfields, a smaller family, shifted the kitchen to the house extension where they installed a modern green enamel fuel stove in the fireplace. The Oldfields opened up the sides of the old kitchen as a buggy house, later a garage.

But CDHS needed the Oldfields' kitchen for its library (and later, photo gallery) and so a new display kitchen was constructed in one of the back rooms of the house, complete with fireplace crane. The Society also needed a rustic space for exhibiting farm technology, for which purpose members re-walled the old kitchen frame in 1964-66 with slabs from a number of local sources. ${ }^{15}$ The introduction of foreign slabs and Wardle's suggestion that the building had been relocated coloured views of the building's authenticity for forty years. It is still listed as relocated on the Register of the National Estate. Thus the Blundell's kitchen became a shed, the reputation it retains to this day.

The house was now open for public visitation. Volunteers staffed it for twohour blocks, morning and afternoon, but there was always a need for more and a few sturdy souls carried a disproportionate burden - a pattern that persisted throughout the CDHS tenure of Blundell's. Holiday periods induced surges of tourists. In the first decades, Canberra people brought their guests: international government officials, conferees and their spouses were taken along to see Australian history; schools began to visit, frequently without notice; travellers arrived late in the afternoon and volunteers stayed on so as not to disappoint them. Pleasantly autumnal Easter always saw large crowds of up to 600 a day, causing some alarm and occasional damage. In the 1960s, Canberra had relatively few tourist attractions beyond the official sights and Blundell's rapidly became a prime site. By 1972 it was 'rated no. 4 on the tourist points of interest in the ACT. ${ }^{, 16}$

The public role of the house as a tourist site gave it a legitimacy in the marketplace which it could never realistically sustain in terms of meeting its operational costs but whose promise seemed to legitimate small subsidies. The relationship with government created by more or less regular grants came to define a new phase of the house's existence: a sort of client with the moral claim of ancient value combined with the potential of making an independent go of it. The inexplicit expectations and compromises which this status generated have come to define a whole class of small heritage sites in a condition of respectable 
poverty. Blundell's Cottage and its ilk are now the pitiful relations of the heritage phenomenon - a difficult circumstance with an unpromising future.

\section{THE TIDE OF HERITAGE CONSERVATION IN CANBERRA}

Very soon after its foundation, CDHS had protested the demolition of Glebe House, the 1871 Rectory of St John's church, another Campbell foundation. 'What is to become of... the most important private relic of older settlement in the city area? Is it to go the way of Acton House?' thundered the President to the Canberra Times in 1954. ${ }^{17}$ The answer was unhesitating: Canberra's development marched onwards and Glebe House was demolished. But the next old building to be threatened, Oldfield's, became the tipping point for the conservation of Canberra's pre-federal capital heritage.

There was some positive response to the CDHS submission on Oldfield's house, though it was soon undermined by the notion that a plaque on the spot would be sufficient commemoration. However, in the way of things in Canberra, the official and the personal roles of individuals intersected to push along certain projects. NCDC Associate Commissioner Grenfell Rudduck urged comrades in $\mathrm{CDHS}$ to maintain the pressure to conserve the house. He may have been the author of the 1961 memo which analysed the claims of the house: 'it lacks historical interest, and has no particular architectural or structural significance... On the other hand... the cottage is an old building within the Australian context... It has been argued that the Government has an obligation to the future, to preserve links with the past, and... in this respect the [value of the] cottage, as a piece of life long past, will increase as the years go by. ${ }^{, 18}$

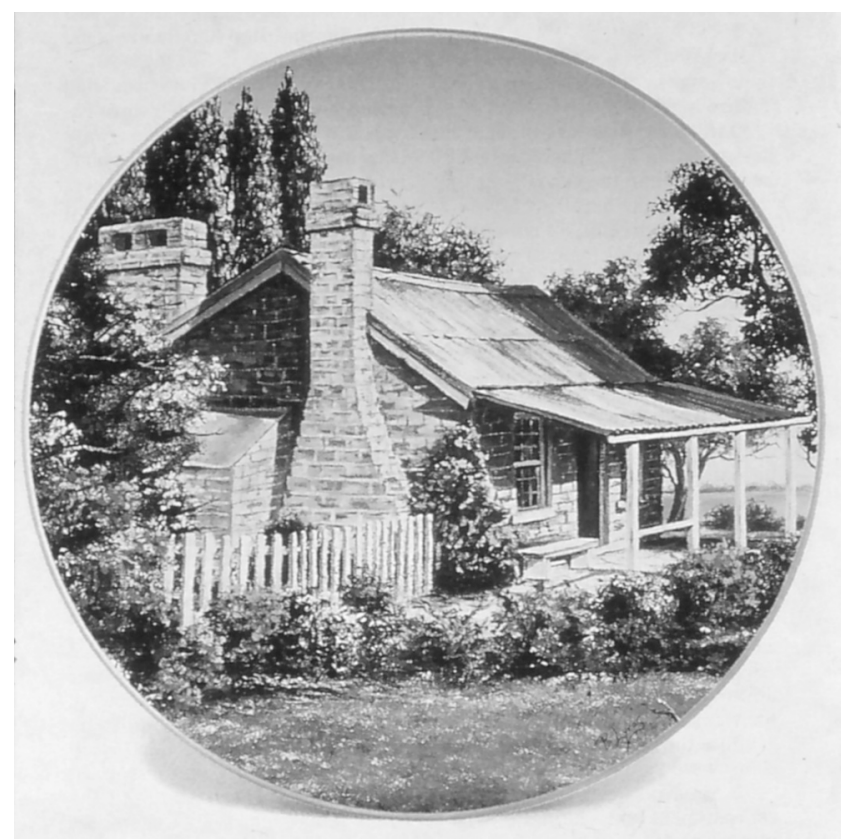

A private company capitalised on the romantic charm of the cottage to produce this 'collectable' plate in 1992.

(Photograph Linda Young) 
The preservation view was supported in a small way by eminent British planner William Holford, who was invited by Prime Minister Menzies in 1957 to advise on the future development of Canberra. ${ }^{19}$ Holford envisaged the planned new parliament house on the river plain by the shore of the lake and suggested that the cottage could be retained as 'a symbolic foil for the majesty of the Parliament House opposite. ${ }^{20}$

Thus the small vernacular house survived by virtue of the semiotic inspiration of its location. Yet Oldfield's was not the only house that should have made way for Canberra's landscaped lake: two others were demolished in 1961-62. There seem to have been regrets, but no protests, about the demolition of Springbank House, on an 1831 land grant and with buildings that may have dated to the 1840s, and Riverview, formerly the dairyman's house on Yarralumla estate, which was built in a stark Gothic style in 1889 and surrounded by older slab buildings. ${ }^{21}$ At the turn of the 1960s, Canberra was still a country town with capital city grafts. Evidently, rundown timber houses were too close to the mundane to be perceived as monuments, even by the Historical Society.

Fifteen-odd years before the rise of 'heritage' in Australia, it is familiar to note that Herman described Oldfield's as 'a minor farmhouse of the period' with 'a naïve charm that is vaguely linked to Georgian architecture'. ${ }^{22}$ Herman was the most scholarly of the tiny handful of architects interested in Australian historic buildings and author of Early Australian Architects and their Work (1954). His view of the structure wouldn't be gainsaid by a heritage professional today but the Holford view of its representational value would now be judged more important. Holford's opinion would now be expressed in terms of the Burra Charter and Australian Heritage Commission concepts of historical significance, justifying the preservation of the house as evidence of a significant way of life.

This was first articulated twenty years later in a 1983 conservation plan undertaken by heritage architect Eric Martin, then of Philip Cox and Partners, for the Department of Housing and Construction, the agency which managed Commonwealth property. The report demonstrates the surge of theory and practice that fuelled the invention of heritage in Australia in the 1970s. With historical and archaeological contributions by Jonathon Winston Gregson, the Cox report reviewed the management of the house in the 1960s and 1970s, judging that the place had been 'unsympathetically modified' by the Herman restoration and that CDHS had produced 'many introduced elements and inaccurate details. ${ }^{23}$ The core of this critique expressed the transition (discussed below) from a simple valuing of the generic 'old' to a nuanced articulation of historic significance.

The Cox report was framed by the perspectives of the new heritage professionalism. It recommended a suite of maintenance repairs, the restoration of some known elements and the addition of numerous security details, almost none of which was implemented, for the house management had been thoroughly captured by its ardent volunteer committee. ${ }^{24}$ In a phenomenon well known by 
anecdote but rarely written about, the committee 'played house' to its heart's content, informed by the bush backgrounds and antiquarian tastes of many of its members. In the 1960s and 1970s, these were the normal standards of a voluntary museum, and rather than launching into a critique of its historiography, it is right to acknowledge that without the committee's passion and energy, the house may not have survived at all and a significant collection might never have developed.

But the Blundell's committee that had made the house into a vigorous museum, local sight and tourist attraction, inevitably turned into an old guard as the years went by and new members joined the Historical Society. On the evidence of names recorded in the CDHS Newsletters and committee minutes, there were some twenty five really active volunteers for longer or shorter periods in the first twenty years, many taking on specific collection management responsibilities as well as visitor greeting and guiding. The presiding geniuses were Len and Connie Young (unrelated to the author), involved since the very beginning, respectively as odd-job man, money manager and instructor in country trades, and as hostess, interior designer, needlewoman and Newsletter scribe. They acquired a vast proportion of the collection: 'The two of them had a keen nose for clearing sales and would be off in their little orange VW, far and wide in southern NSW, coming back with this or that objet d'art, or perhaps just objet, which they felt might come in [useful] at Blundell's. ${ }^{25}$ Connie slowed down after falling and dislocating her shoulder on duty in 1982, and Len handed in his keys four years later, aged 89. By then they were not impressed with the new directions then being proposed for the house.

The shift was specified in a report commissioned by CDHS in 1986, 'Review of Management and Interpretation', by Stephen Dovers, then an educational consultant. He made the central point that the Society was divided between regarding the house as a pioneer memorial rather than a museum with an essentially educational mission. ${ }^{26}$ The report also documented unacknowledged weaknesses in current operations: it was hard to keep volunteer staff, especially in winter and in the absence of a decent toilet; the existing volunteers needed regular coordination; the collection deserved professional attention which hadn't been provided by an untrained unemployment scheme 'curatorial assistant' appointed in 1984; and both collection and personal security conditions in the house required upgrading. ${ }^{27}$ Dovers made intelligent recommendations that were eventually implemented ten years later.

In 1988, the house committee renamed itself a Board of Management for strategic effect and developed closer relations with the newly constituted National Capital Planning Authority (NCPA). The Board now adopted historical education as its explicit role and asserted the new differences with a change of name: 'the cottage in the Parliamentary Triangle called Blundell's'. ${ }^{28}$ A new crop of volunteers threw themselves into the fray, among them Beth Knowles and Esther Davies, teachers respectively of drama and history. They brought new standards and techniques to displays, spiels and activities with a focus on the social history 
of the inhabitants as workers rather than pioneers. Knowles researched and wrote an authoritative history of the house, published by the Society in $1990 .{ }^{29}$ The NCPA funded a new conservation plan by heritage architect Peter Freeman in $1994 .{ }^{30}$ Important for the depth of physical examination and assessment of the buildings by Pip Giovanelli, its major outcomes were long-delayed maintenance and work in 1997 to stabilise the slab kitchen whose posts and bottom plates had substantially rotted away. ${ }^{31}$

Recognising the role of the house in local tourism, the Department of the Interior had funded the first paid staff member (an 'attendant'), employed for two hours a day in $1966 .{ }^{32}$ The subsidy was reduced in 1972, initiating years of annual tussle with government for ongoing support. Employment schemes sometimes made opportunities to take on further staff such as a cleaner in 1983 and a curatorial assistant in 1984 but they were fleeting appointments. ${ }^{33}$ In 1988 the Blundell's Board of Management persuaded the ACT government to pay for a part-time manager, increasing cottage opening hours from twelve to forty two per week. ${ }^{34}$ The experiment established a new standard of public accessibility and accountability in the management of the house, concomitantly introducing an anxious budget watch every month. By 1990, paid staff had been reconfigured as two or three part-time interpreters recruited from university history and heritage courses. ${ }^{35}$ Volunteers still staffed the site most days, but the volunteering environment was changing. There were fewer unemployed women. Retired people were healthier and actively engaged elsewhere. And new Canberra museums and other organisations offered alternative opportunities to volunteers.

A few troupers remained from the very earliest days, some stalwart individuals and couples dedicated themselves for periods of years but inevitably burned out and further generations of occasional volunteers came and went. Ever more demanding standards of accountability for funding made applications and acquittals a burden for volunteer committees and priorities in government support for heritage shifted from operational grants to project grants, making it difficult for a marginally profitable operation such as the cottage to stay viable. In 1990 and again in 1992, there was talk of returning the cottage to the Commonwealth. ${ }^{36} \mathrm{~A}$ strategic plan prepared by the Board of Management in 1998 showed that the increasingly professional standards now expected of a voluntary museum required more time and energy than $\mathrm{CDHS}$ members were able to commit: 'services and standards at the Cottage have risen well past the level of infrastructure resources available'. ${ }^{37}$ The introduction of the GST was the decisive factor. The grant for wages would propel CDHS's total income into an unwelcome tax scenario. ${ }^{38}$ After thirty five years, the house needed a new manager and the latest avatar of the NCDC, the National Capital Authority, took over responsibility in July $1999 .{ }^{39}$

\section{Presenting history Via heritage}

Blundell's Farmhouse was officially opened on Canberra Day, 12 March 1964, with an intergenerational ceremony of handing on the door key. Arthur Campbell, 
descendant of the Duntroon Campbells, gave the key to Bill Ginn, grandson of the original Ginns, who gave it to Jack Blundell, born in the cottage in 1878, who gave it to Eric Oldfield, a cousin of Harry, who presented it to the Minister for the Interior, Doug Anthony, who opened the cottage and handed the key to CDHS President John Whelen. Two hundred members and friends looked on as the Minister accepted a peppercorn as token rent. ${ }^{40}$

When CDHS renamed Oldfield's farm 'Blundell's Farmhouse' in 1963 the Historical Society extended the history of the national capital from a creation story of the planned city to a mythic foundation by pioneer Everyman. To the irritation of Ginn descendents and Oldfield relations, the longest-dwelling inhabitants were honoured with a singularising identity. ${ }^{41}$ In casting it as a 'farmhouse', the Society asserted a cosy homeliness that was different from the plain farm the place had been in the minds of Canberrans who knew the Oldfields.

As enacted in the door key ceremony, the meanings established by the name change introduced ideas of deep local roots in a rural place. It was a specimen of the taste for explaining Australian history as a discourse which John Hirst subsequently named the 'pioneer legend'. ${ }^{42}$ Pioneers represented the triumph of white settlement by working the land, enduring hardship and building property and dynasty. They might be large land-holders who advanced from a hut to a mansion. But even a bushman or rural labourer - and by extension, his wife could qualify as pioneers and a humble cottage could become their monument. The CDHS aim was explicit in asserting that authentic restoration and furnishing of the Farmhouse would constitute 'a memorial to Canberra and Australian pioneers' by showing 'how the pioneers lived. ${ }^{43}$

The concept of pioneers structured the collection. In 1974, Connie Young recalled Manning Clark's advice to the Society many years ago: he suggested they read On Our Selection for the flavour of pioneer life. 'Now we have Blundell's bursting at the seams with what Dad, Dave and Mabel might have lived with', wrote Connie. ${ }^{44}$ The furnishings were acquired by donation and purchase from local property auctions, mostly in the 1960s, to represent life in the period 1858$1900 .^{45}$ Yet the committee could not resist the offer of occasional exotic objects such as a silver-mounted toilet set, even acknowledging that it 'may well be a little out of character in a pioneer family's humble cottage' or technically irrelevant pieces such as a convict leg iron from Norfolk Island. ${ }^{46}$ The more picturesque donations were described in the Annual Report and the Newsletter, including a chestnut roaster, a long silver-handled buttonhook and a portable organ (harmonium), all donated in 1964. Chance delivered other objects such as the ruby-font kerosene lamp, deposited on the back door mat in 1966. Some items had local origin, such as two trunks of goods from the Brindabella Franklin family received in 1974, containing a melange of bits and pieces. ${ }^{47}$ Occasional items arrived with a provenance to cottage inhabitants, mainly Blundells. ${ }^{48}$ It was eclectic, yet it moved its visitors as well as its collectors. One visitor contributed an untitled poem that spoke of her response to the authenticity of the pieces: 
For the trinkets here and there

The lamp for kerosene and copper kettle,

The chiffonier or sideboard you just don't see anywhere,

And the metal things were really made of metal.

There's a bamboo whatnot stand with its crowd of curios

And a patchwork vase that's made of china bits,

The needlework so fine on those handstitched baby clothes -

You can see the mother stitching as she sits. ${ }^{49}$

The collection can be seen as fairly typical of a historical society, inspired by a sense of the reliquary value of old ways in olden days. The antique character of objects, often validated by personal recollection, was generally regarded as more important than precise details of their original location or ownership, though local family names and sites were always recognised as specially relevant. The patina of use was valued to the point that broken and incomplete objects were commonly taken into the collection. This created a role for a line of cottage handymen to improve objects with a lick of black or silver paint for metals, and pale green for wooden items. These 1960s finishes are still apparent in the collection. Such practices are now frowned on but the significance of the collecting focus on the humble material culture of rural workers is now valued highly, for the state museums came much later to folk or social history. In this, the collection contains vernacular and ephemeral gems - such as a coir dish brush, a bush desk, a Canberra-made Coolgardie safe - that would be difficult and expensive to gather again.

Domestic goods and rural technology were not the only expressions of the pioneer past deemed worthy of collecting. The garden was planted with cuttings from other local sites such as an olive from Rosebud Apiary, white iris from Charnwood house, succulents from Hill Station. ${ }^{50}$ A portion of the garden was set with stones collected as relics of ancient buildings of the district: a large grey slab from Orroral homestead; a corner stone from Harp of Erin pub in Queanbeyan; a piece of granite from Mr Sheedy's grandmother's oven; a cornerstone from Towrang convict barracks; stones from the Cameron home at Land's End and the Spinney, no2 Mugga Way. ${ }^{51}$ I quote the details of the stones to emphasise their importance as relics, matter imbued with meaning because of their provenance. It is telling of the nature of relics that these stones have become lost due to landscaping around the house: their significance unrecognised, they appear to have been removed in the 1980s.

The character of heritage significance shifted in this decade. Memorialisation of 'the past as lived by ordinary, decent working folk last century on the lonely Canberra plain ${ }^{, 52}$ was transmogrified by the criteria developed by the Australian Heritage Commission. Thus the Statement of Significance formulated in 1983 in the Cox conservation plan restated the house's value as demonstrating a way of life: 'one of few stone buildings of its type, servants' quarters on a large agricultural estate, that have survived the consolidation of squattocracy'. ${ }^{53}$ This 
was a deliberate revision of the pioneer Farmhouse ideal, stressing the subaltern status of the house occupants. In further discussion, author Martin - an architect - stressed the form and function of the building by undermining the meanings of the collection: 'the cottage is significant because it is a workman's cottage and not because it is old and historical and insertion of old artefacts and materials does not necessarily add to the place as in this case many have detracted from its true significance and integrity. ${ }^{, 54}$ Martin here epitomised the shift from inchoate respect for age value to the professionalist focus on built fabric which characterised the new concept of heritage. His conservation plan's principal recommendation was to cement this understanding by having the cottage and its surrounds entered on the Register of the National Estate. ${ }^{55}$

It was soon achieved and the house was registered about 1984 as: 'Servants' quarters of a large early nineteenth century agricultural estate which is significant in being one of the few stone buildings of its type to have survived intact in the ACT. It is important for the way it reflects a way of life on such an estate. ${ }^{56}$ There was little solid research evidence for this statement, in common with a great many other entries on the Register of the National Estate, but it was essentially sound.

Nonetheless, when the NCDC's then-incarnation, the NCPA, joined the heritage bandwagon with its Sites of Significance in the ACT, published in 198890 , the house's social history presented as less important than its landscape value: 'This link with the past, together with the location of the site in urban Canberra, where few historic buildings of similar age still remain, are the primary reasons [to preserve it]. ${ }^{57}$ It could be seen as odd that the various heritage assessments make so little of the symbolic aspect of the house's survival and incorporation into the fabric of federal Canberra. A large proportion of visitors has always assumed the house is relocated, pointing to a failure to interpret the growth of the twentieth century city around it. ${ }^{58}$ The reason for the absence of acknowledgement of semiotic significance is that the assessment apparatus of neither the Burra Charter nor the Australian Heritage Commission easily recognises the concept other than as an aspect of historic ways of life and values. In the period of the heritage profession's discovery of history from the bottom up, social history expressions tended to overwhelm other insights.

In this light it is telling to observe that the 1994 statement of significance by Peter Freeman identified aesthetic significance in the site in the irregular and vernacular charm of its buildings and landscape. ${ }^{, 59}$ Freeman was somewhat wishful: the vernacular charm had been reduced to two buildings and a retropicket fence in 1963, in a thoroughly NCDC-landscaped lakeside verge - though admittedly, the trees, probably of Oldfield vintage, were now imposing. More important was Freeman's recording of the social significance of the house, 'valued by many of the Canberra and regional community as a remnant of the past now obliterated by Federal Capital development. ${ }^{60}$ This had become explicit in a public workshop held on site, when the plaintive cry to prevent 'them' knocking down or moving the house arose again and again. It was never in 
danger but the fear that it could happen indicated considerable community distrust of Canberra's planning agencies.

In the wake of the first real conservation work on the building since Morton Herman's period, the Board of Management implemented an internally-developed interpretation plan, funded by the NCA in $1997 .{ }^{61}$ It was based on an evaluation of the integrity and condition of the collection and an analysis of comparable rural life exhibits, now augmented by high quality presentations at Lanyon and Mugga Mugga, both under the aegis of the ACT Government. Lanyon had the advantage of an intact total structure of big house, outbuildings and landscape. Mugga had the advantage of an original collection in an unrestored building complex. By comparison, Blundell's amounted to a compromised pair of buildings housing a predominantly unprovenanced collection in fairly degraded condition. It cast the house as unsustainable in the competitive environment of other heritage attractions. In this circumstance, the decision was made to offer visitors a unique experience, unavailable elsewhere. By removing the handful of valuable and vulnerable items from display, it became possible to invite visitors to 'please touch' and thus experience the materiality of the past. In the long term, this would be an unsustainable way to present the house and collection but the committee now judged the house a finite resource, being unable to match the professional resources and standards obtaining in the two government-funded house museums. The 'please touch' approach was certainly well received by visitors. But in the event, CDHS relinquished control of the house and sold the collection to the NCA in 1999. The interpretation of local history has since reverted to the conventional.

The house now known as Blundell's Cottage offers a not-unusual story of the transition from lived-in house to relic to heritage site to history-flavoured tourism sight. The decline in its fortunes is a function of tremendous changes in the professionalisation of heritage and its economics since 1963. Those changes have been good for heritage, in establishing the genre and standards for managing conservation, but bad for amateur historical societies and their voluntary efforts to maintain old things.

Some historical societies have given up the collections they built up in the 1960 s and 1970s to new professionally-resourced and funded museums. They now focus on local history research, writing and talking. A few old historical societies have been swept into the professionalising machine of local government-funded regional museum apparatus and adapted to modern conditions with modern resources. But many more have been sideswiped on the freeway of heritage professionalism and now moulder on the verge, dismissed for their old fashioned poverty.

In this manifestation, historical societies sustain the popular prejudice against musty-dusty museums of boring objects, receiving little recognition for the role they played in preserving local history before there was a heritage profession to 
do it for them. It is a difficult equation. Amateur historical society practice has been devalued and new professional standards have made it even harder for it to remain useful, let alone be acknowledged as valuable. At the same time, the perspectives and techniques of the heritage profession have certainly improved the quality of research, conservation and interpretation on local sites. Reconciling the old but still popular concept of pioneers with modern perspectives on inclusivity, diversity and relativity could now be both just and effective.

\section{ENDNOTES}

${ }^{1}$ C.E.T. Newman, The Spirit of Wharf House: Campbell Enterprise from Calcutta to Canberra 1788-1930, Sydney, Angus and Robertson, 1961, pp145-7.

${ }^{2}$ Newman, p182.

${ }^{3}$ Beth Knowles, The Cottage in the Parliamentary Triangle: A social history of the building known as Blundell's, Canberra, Canberra \& District Historical Society, 1990, pp29-33.

${ }^{4}$ Knowles, p34-42. Administrator, Federal Capital Territory, 'Duntroon: Areas Occupied and Tenants of Workmen's Cottages': NAA, series A202, item 13/4538.

${ }^{5}$ Knowles, pp43-48.

${ }^{6}$ Morton Herman, 'Report to the National Capital Development Commission, Canberra ACT, on Oldfield's Cottage, Scott's Crossing Road, Canberra', 22 August 1961.

${ }^{7}$ Knowles, p53.

${ }^{8}$ CDHS Newsletter 41, July 1963.

${ }^{9}$ CDHS Newsletter 79, Jan 1967.

${ }^{10}$ CDHS 'Annual Report', 1985-86, p.7; 'Annual Report', 1990-91; CDHS Newsletter, no 355, Feb-Mar 1998, p3.

${ }^{11}$ CDHS Newsletter 108, Nov 1969, p3; Patience Wardle (ed), A Visit to Blundell's Farmhouse, Canberra, CDHS, 1972, p35.

${ }^{12}$ CDHS Newsletter 123, May 1971.

${ }^{13}$ Department of Home Affairs, Correspondence Files, Valuation of FCT Holdings (Moriarty and Smith valuations), 'Acquisition of J.E.R. Campbell, Duntroon Estate, Parish of Canberra': NAA: series A358, folio 21 , schedule 3.

${ }^{14}$ Wardle, p29.

${ }^{15}$ On the sources of additional slabs, see CDHS 'Minutes', 12 November 1963; 7 January 1964; CDHS Newsletter, 221, Feb 1981; 245, June-July 1983.

${ }^{16}$ CDHS 'Annual Report', 1971-2, p4.

${ }^{17}$ Canberra Times, 30 March 1954. Acton House, parts of which may have dated from 1826, was demolished in 1941.

${ }^{18}$ Cited in Freeman Collett and Partners (Peter Freeman, Pip Giovanelli), 'Blundells' Cottage Precinct

Conservation Management Plan', 1994, p57.

${ }_{19}$ Paul Reid, Canberra Following Griffin: A Design History of Australia's National Capital, Canberra,

National Archives of Australia, 2002, pp237-9.

${ }^{20}$ Freeman, op cit.

${ }^{21}$ Margaret Kaye, 'The Kaye Family of Klensendorlffe's and Springbank', in Ann Gugler, True Tales from Canberra's Vanished Suburbs of Westlake, Westridge and Acton, Fyshwick ACT, On Demand Press, 1999, pp339, 342; Richard Clough, 'Demolishing the old farmhouse, Yarralumla Bay', 1962, transparency, NLA 14324452-313.

${ }^{22}$ Herman, op cit, pp1-2.

${ }^{23}$ Philip Cox and Partners (Eric Martin, with Jonathon Winston Gregson), 'Blundell's Cottage: Conservation Study Report', April 1983, ppii-iii.

${ }^{24}$ ibid, pp61-65. Much the same recommendations were made in the 1994 conservation plan, and were implemented thereafter.

${ }^{25}$ Tribute by Pat Wardle on Len's retirement, CDHS Newsletter 279, November 1986, p9. Connie died in 1987: CDHS Newsletter 285, Jun-July 1987; Len died in 1988: CDHS Newsletter 297, Sept 1988.

${ }^{26}$ Stephen Dovers, 'Blundell's Farmhouse: Review of Management and Interpretation', September 1986, p3.

${ }^{27}$ ibid, pp28-34.

${ }^{28}$ CDHS Newsletter 293, Feb-Mar 1988, pp5-6.

${ }^{29}$ Knowles, op cit.

${ }^{30}$ CDHS Newsletter 333, June-July 1994; Freeman op cit.

${ }^{31} \mathrm{CDHS}$ Newsletter 355, Feb-Mar 1998, p3.

${ }^{32}$ CDHS Newsletter 79, Jan 1967; Knowles, p57.

${ }^{33}$ CDHS Newsletter 242, March 1983, p7; Newsletter 258, Oct 1984, p9.

${ }^{34}$ CDHS Newsletter 293: Feb-Mar 1988, p5-6.

${ }^{35}$ CDHS Newsletter 308: April-May 1990, p3. 
${ }^{36}$ CDHS 'Annual Report', 1990-91; CDHS Newsletter 319, March 1992, p4-5.

${ }^{37}$ CDHS 'Annual Report', 1997-98.

${ }^{38}$ CDHS Newsletter 362, Apr-May 1999, p9-10.

${ }^{39}$ CDHS 'Annual Report' 1999-2000.

${ }^{40}$ Newsletter 47, March 1964; 48, April 1964; 274: May 1986.

${ }^{41}$ Shirley Purchase, 'Adventures in bookmaking', Canberra History 1953-2003: Celebrating 50 Years,

Canberra, CDHS, 2003, p59.

${ }^{42}$ J.B. Hirst, 'The Pioneer Legend', Historical Studies, vol 18, no 71, October 1978.

${ }^{43}$ CDHS Newsletter 38, Dec 1962; Newsletter 51: July 1964.

${ }^{44} \mathrm{CDHS}$ Newsletter 155, August 1974, p10.

${ }^{45}$ Wardle, p5.

${ }^{46}$ CDHS Newsletter 131, Mar 1972, p5.

${ }^{47}$ CDHS Newsletter 150, Feb 1974, p.4.

${ }^{48}$ CDHS Newsletter 129, Dec 1971, p4; 132: Apr 1972.

${ }^{49}$ Extract from Merilyn Stevens' poem, 1980 (Blundell's file, CDHS); printed in CDHS Newsletter, Sept 1980

${ }^{50}$ CDHS Newsletter 132, Apr 1972, p15-16; Newsletter 188, Nov 1977, p6.

${ }_{51}^{51}$ CDHS Newsletter 84, July 1967; Newsletter 126: Sept 1971, p3; Newsletter 213, April 1980, p5.

${ }^{52}$ CDHS Newsletter 116, Sept 1970, p5.

${ }^{53}$ Cox, p57.

${ }^{54}$ ibid, p58.

${ }^{55}$ ibid, p61.

${ }^{56}$ Quoted in Freeman, p56. The entry, no 13324, has since been updated and now calls the house a 'residence built for a station hand as part of the vast Duntroon estate'.

${ }^{57}$ Sites of Significance, 'Inner Canberra', Canberra, National Capital Planning Authority, 1988-90, pp54-5.

${ }^{58}$ CDHS Newsletter, 160, Feb 1975, p2.

${ }^{59}$ Freeman, p65.

${ }^{60}$ ibid, p66.

${ }^{61}$ CDHS Newsletter, 349, Feb-Mar 1997, pp3-4. 